\title{
ARISAN SEBAGAI MODEL MENINGKATKAN POIN KEANGGOTAAN TUPPERWARE DALAM PERSPEKTIF AKUNTANSI
}

\author{
Aminatus Zakhra1, Ach Fawaidul Anam²*, Amaliyah ${ }^{3}$ \\ Universitas Islam Madura ${ }^{1 *}$, Universitas Islam Madura ${ }^{2}$, Universitas Airlangga ${ }^{3}$ \\ Email: zakhra1982@gmail.com ${ }^{1 *}$, amaliyah@ vokasi.unair.ac.id ${ }^{2}$
}

\begin{abstract}
Artikel info
Artikel history:

Diterima 06 Mei 2021

Diterima dalam bentuk revisi 11 Mei 2021

Diterima dalam bentuk revisi 18 Mei 2021
\end{abstract}

\section{Keywords:}

social gathering; profit, accounts receivable; cost.
Abstract: The purpose of this study is to analyze the sales of Tupperware based on arisan from an accounting perspective as an effort to achieve the target points of Tupperware members. This study used a descriptive qualitative approach in Pamekasan Regency. Data collection methods used in the study were observation, interviews, and documentation. Data analysis techniques in this study used data reduction, data presentation, and drawing conclusions. The results of this study indicate that arisan income can be in the form of financial and non-financial. Financial income is in cash, while non-financial income is in the form of member points. The collected member points can be exchanged for products and an increase in membership level. Accounts receivable in the arisan system are contributions from each arisan member. Costs in the arisan system are costs incurred by Tupperware members when attending arisan such as transportation, consumption, and bailout funds for arisan money when there are arisan members who are late or don't pay. Up to date, there are several studies that have topic relevance, but there is no topic that states that arisan can increase membership points. From these activities, members can level up due to sales through arisan. Therefore, this research can contribute to the field of economics, especially accounting.

Abstrak: Tujuan penelitian ini untuk menganalisis penjualan Tupperware berbasis arisan dalam perspektif akuntansi sebagai upaya pencapaian target poin member Tupperware. Penelitian ini menggunakan pendekatan kualitatif deskriptif yang dilakukan di Kabupaten Pamekasan. Metode pengumpulan data yang digunakan dalam penelitian adalah observasi, wawancara, dan dokumentasi. Teknik analisis data dalam penelitian ini menggunakan reduksi data, penyajian data, dan penarikan kesimpulan. Hasil penelitian ini menyatakan bahwa pendapatan arisan bisa berupa finansial dan non finansial. Pendapatan finansial berupa uang tunai sedangkan pendapatan non finansial berupa poin member. Poin member yang terkumpul dapat ditukar dengan produk serta peningkatan level keanggotaan. Piutang dalam sistem arisan adalah iuran dari setiap anggota arisan. Biaya dalam sistem arisan adalah biaya yang di 
Kata Kunci:

Arisan; laba; piutang; biaya. keluarkan oleh member tupperware ketika hadir dalam arisan seperti transportasi, konsumsi, serta dana talangan uang arisan ketika ada anggota arisan yang telat atau tidak membayar. Keterbaruan ada beberapa penelitian yang memiliki relevansi topik, namun belum ditemukan topik yang menyatakan bahwa arisan dapat meningkatkan poin member keanggotaan. Dari kegiatan tersebut, member dapat menaikkan level karena penjualan melalui arisan. Oleh karenanya, penelitian ini dapat memberikan kontribusi pada bidang ilmu ekonomi, khususnya akuntansi.

\section{Coresponden author: Ach Fawaidul Anam}

Email: zakhra1982@gmail.com artikel dengan akses terbuka dibawah lisensi

\section{Pendahuluan}

Strategi penjualan pada saat ini mengalami peningkatan dalam segi perencanaan maupun dalam segi pemasarannya. Menurut (Kartajaya, 2007) menyatakan bahwa persaingan semakin ketat seiring dengan derasnya arus perdagangan bebas, secara otomatis membuat kompetisi datang dari segala penjuru baik domestik maupun global. Selain itu, para pebisnis membentuk strategi agar produk tersebut laku dan diminati oleh masyarakat, serta memudahkan para pembeli mendapatkan produk. Penjualannya bisa dilakukan berbagai macam layanan seperti halnya jual beli secara online dan offline, COD, dan MLM. Sistem penjualan Tupperware di fokuskan bagi penggemar produk tersebut, khususnya ibu rumah tangga dan masyarakat golongan menengah ke atas di Kabupaten Pamekasan.

Keberadaan bisnis Tupperware ini bisa dikatakan masuk dalam bisnis kategori multi level marketing (MLM), namun yang menjadi perbedaan sistem karir Tupperware ini adalah dijual dengan sistem party dimana terdapat tuan rumah yang mengundang tamu, lalu memperkenalkan produk Tupperware terbaru, misalnya yang ada pada buku katalog tahunan dan buku promo bulanan. Selain itu bisa menggunakan sistem promosi dan sistem pemasaran melalui media sosial seperti facebook, instagram dan aplikasi lainnya untuk lebih dikenal masyarakat luas. Berbagai macam strategi pemasarannya tujuannya hampir sama dengan perusahaan yang lainnya adalah untuk menghasilkan laba/keuntungan.

Menurut (Johan, 2014) menyatakan bahwa adanya pengaruh penerapan target costing terhadap peningkatan laba kotor dan dapat menghemat biaya. Karir di Tupperware, mereka mempunyai beberapa strategi salah satunya strategi pemasaran dengan System Party dan memasarkan katalog baik secara offline maupun online. Selain dengan katalog biasanya para member memasarkan produk dari door to door, karena hal itu belum memenuhi target maka member Tupperware mengadakan sistem penjualan secara cicilan, akan tetapi ternyata sistem secara cicilan dianggap kurang menguntungkan dan beresiko akan keterlambatan para anggota dengan berbagai alas an untuk membayar cicilannya. Member Tupperware 
berinisiatif untuk melakukan penjualan dengan sistem arisan atau kegiatan yang melibatkan orang banyak. Arisan bisa menarik konsumen lebih cepat agar bisa membeli produk kita dengan kesepakatan yang sudah ditentukan terlebih dahulu, dan member yang mengadakan arisan bisa mudah mendapatkan poin lebih cepat dari penjualan produk Tupperware.

Pengadaan arisan di dalam pencapaian target poin di Tupperware mereka mendapatkan pendapatan, dan mengeluarkan biaya, serta juga akan mendapatkan piutang. Kegiatan arisan akan berkorelasi dengan dimensi investasi atau piutang karena arisan merupakan sebuah kegiatan mengumpulkan dan menyalurkan dananya kepada masyarakat. Kegiatan mengumpulkan dana terdiri dari dua dimensi, yaitu pihak yang mengeluarkan dana dan pihak yang menerima dana.

Menurut (Baihaki \& Malia, 2018) menyatakan bahwa pendapatan adalah dana yang terkumpul dari iuran setiap anggota arisan yang membayar tiap periode. Biaya dalam arisan adalah biaya yang dikeluarkan oleh setiap anggota arisan baik biaya transportasi atau konsumsi karena kebanyakan anggota membawa kendaraan untuk berkumpul dan membayar iuran yang wajib bagi anggota arisan. Piutang dalam arisan adalah investasi dari setiap anggota arisan yang dibayar tiap periode. Sistem arisan dalam perspektif akuntansi terdiri dari pendapatan, biaya, dan investasi atau piutang. Pendapatan adalah dana yang terkumpul dari iuran anggota arisan dalam setiap periode. Biaya adalah dana yang dikeluarkan oleh anggota arisan baik biaya transportasi atau konsumsi. Piutang atau investasi dalam arisan adalah investasi yang didapat dari setiap anggota.

Arisan telah berkembang menjadi kegiatan mengumpulkan dana yang kemudian bisa diberikan dalam bentuk barang tertentu kepada pemenang undiannya. Anggota arisan juga bisa mendapatkan manfaat dari barang yang diinginkan tanpa biaya tambahan bunga atas perolehan barang yang bisa dibayarkan secara angsuran dalam bentuk nominal yang disepakati didalam pembayaran arisan. Pola arisan tersebut menjadi sistem penjaminan arisan dan sistem penjamin asuransi sosial dalam memenuhi kebutuhan sesama anggota, yakni membayar sejumlah nominal tertentu. Arisan juga tidak hanya mengumpulkan uang, tetapi kadang juga barang, bahkan mengumpulkan potensi yang dimiliki anggotanya.

Kenyataannya, arisan memang menjadi sarana untuk menyeimbangkan potensi konsumsi dengan potensi menabung. Jika menabung didasarkan pada usaha sadar untuk menyisihkan sebagian dananya bagi masyarakat yang memiliki kelebihan penghasilan. Akan tetapi, dengan mendapatkan barang secara arisan, maka masyarakat dengan penghasilan rendah pun akan juga memiliki kesempatan untuk melakukan kegiatan menabung dan bahkan bisa menjadi sarana investasi untuk mendapatkan barang yang diinginkan.

Respon masyarakat Pamekasan terhadap adanya Tupperware itu cukup baik karena fitur dan fungsi yang dimiliki Tupperware, akan menginspirasi masyarakat untuk lebih rapi dan mewah di dalam rumah. Peningkatan omset penjualan yang lebih cepat bagi member Tupperware untuk mencapai target poin salah satunya dengan model arisan dilihat dari perspektif akuntansinya. Adanya latar belakang diatas maka penelitian ini akan meneliti ' Bagaimana arisan Sebagai Model Meningkatkan Poin Keanggotaan Tupperware dalam Perspektif Akuntansi? Penjualan merupakan ujung tombak dari perusahaan dagang dan manufaktur, karena kegiatan mereka adalah menjual barang dagangannya atau barang yang diproduksinya. Banyak metode penjualan ditawarkan oleh perusahaan agar konsumen 
berminat membeli barang dagangannya. Menurut (Mulyadi, 2008) menyatakan bahwa metode-metode penjualan tersebut antara lain: (a) penjualan tunai adalah metode penjualan dimana kas diterima seluruhnya pada saat barang dagangan diserahkan kepada konsumen; (b) penjualan kredit adalah penjualan dimana kas sebagian diterima pada saat barang diterima oleh konsumen sisanya akan diterima pada saat yang akan datang. Penjualan kredit biasanya perusahaan menggunakan termin pembayaran yang tujuannya untuk merangsang konsumen agar segera melunasi sisa pembayaran dengan lebih cepat; (c) penjualan angsuran adalah penjualan yang dilakukan dengan perjanjian dimana pembayarannya dilakukan secara bertahap yakni pada saat barang diserahkan kepada pembeli, penjual menerima pembayaran pertama sebagian dari harga penjualan dan sisanya dibayar dalam beberapa kali angsuran.

Tupperware adalah nama merek terkenal dari peralatan rumah tangga yang terbuat dari plastik yang didalamnya terdapat wadah penyimpanan, wadah penyajian dan beberapa peralatan dapur yang diperkenalkan untuk khalayak umum. Mereka merancang, membuat dan menyebarkan produk-produknya keseluruh dunia melalui perusahaan induknya Tupperware Brands Corporation dan dipasarkan dengan metode penjualan langsung yang sering dikenal dengan julukan Independent Sales Force atau Sales Force. Jumlah saat ini ada sekitar 3,1 juta Sales Force tersebar di seluruh dunia, namun Tupperware sendiri merupakan anak perusahaan yang dimiliki oleh Tupperware Brands Corporation. Pada tahun 2013, pasar terbesar Tupperware adalah Negara Indonesia, disusul oleh negara Jerman. Angka penjualan di Indonesia tahun itu mencapai lebih dari \$200 dengan 250.000 distributor. Pada dasarnya keuntungan menjadi member Tupperware (Sales Force) terbagi menjadi dua. Yaitu keuntungan keuangan (Financial) dan keuntungan non keuangan ( Non Finansial) (www.tupperwarebrands.com 2019). Keuntungan financial tiap-tiap jenjang karir berbedabeda, semakin tinggi jenjang karir, maka semakin banyak keuntungan finansialnya. Sedangkan keuntungan non financial adalah bisa mempunyai banyak teman dan kolega.

Menurut (Meirisa \& Lestari, 2020) menyatakan bahwa arisan hanya dilakukan melalui komunikasi secara langsung dan diperlukan akan kepercayaan dari setiap anggota yang ikut arisan. Budaya di masyarakat kita khususnya di Pamekasan, mulai dari kalangan muda (remaja) dan ibu rumah tangga mengikuti arisan. Kebanyakan dari arisan yang mereka ikuti di ambil secara lotre setiap mingguan maupun sebulan sekali berupa arisan uang. Uang hasil penarikan uang pada setiap anggota yang mengikuti arisan tersebut dikeluarkan untuk diberikan kepada yang akan mendapatkan arisan setiap satu minggu sekali atau satu bulan sekali sesuai banyaknya orang atau peserta arisan. Setiap ibu-ibu rumah tangga yang mengikuti kegiatan arisan harus mengeluarkan uang setiap waktu sesuai nominal yang ditentukan untuk membayar arisan yang mereka ikuti.

Menurut (Lubis, Syahsudarmi, \& Srimulatsih, 2018) menyatakan bahwa arisan adalah agar bisa bersosialisai kepada lingkungan setempat dan memberikan manfaat serta motivasi bagi anggotanya untuk mendapatkan barang atau jumlah nominal yang di inginkan.

Menurut (Hendra, 2018) menyatakan bahwa arisan merupakan suatu kegiatan yang sering diikuti oleh masyarakat muslim, selain itu arisan merupakan kegiatan ekonomi yang didalamnya ada akad-akad.

Disimpulkan bahwa sistem arisan adalah perencanaan pengumpulan uang yang berjangka atau ditentukan dengan aturan yang ditentukan oleh ketua arisan ada arisan yang berbentuk barang dan uang. Adapun keuntungan mengikuti arisan menurut (Wahyu, 2009) 
adalah sebagai berikut: (a) kesempatan untuk melakukan sosialisasi dan memperluas jaringan dan melalui arisan peserta arisan bisa saling mengenal satu sama lain, yang tentunya membuat peserta lebih akrab dengan sesama peserta arisan. Hubungan yang lebih baik ini dapat memudahkan urusan-urusan peserta lainnya diluar, yang berkaitan dengan sesama anggota arisan; (b) kepastian mendapatkan uang atau barang yang jelas nilainya dalam jangka waktu tertentu dengan mengikuti arisan. Para peserta dapat memperkirakan berapa waktu maksimal yang akan dibutuhkan untuk memperoleh uang atau barang dalam jumlah tertentu dan ini tentunya memudahkan peserta arisan dalam membuat perencanaan pengeluaran; (c) sarana untuk "memasarkan sesuatu". Arisan ini juga dapat digunakan sebagai ajang untuk menyalurkan hobi dan bakat, dimana dalam arisan ini anggota bisa menawarkan produk atau jasanya yang mungkin belum diketahui peserta lain, sehingga arisan ini dapat pula dijadikan sebagai pemasaran yang cukup menarik dan relatif murah; (c) mendapat undian di awal periode arisan, berarti peserta arisan mendapatkan pinjaman tanpa bunga. Ini merupakan keuntungan yang tidak pasti bagi peserta arisan, karena peserta tidak tahu kapan akan mendapatkannya baik di awal, di tengah atau akhir periode arisan. Peserta yang mendapatkan di awal ini lebih menguntungkan dibandingkan pinjam uang dari bank; (d) Sarana "berlatih" menabung, khusus bagi yang sulit atau belum terbiasa menabung, arisan adalah pilihan yang baik. Karena, peserta arisan "dipaksa" untuk menyisihkan uang atau barang tertentu pada periode tertentu dan melatih para peserta untuk lebih merencanakan segala sesuatu dengan lebih matang.

Menurut (Saputri, 2018) menyatakan bahwa banyak yang berpendapat kegiatan arisan tidak produktif dan membuang waktu. Padahal, selain sebagai ajang kumpul-kumpul sebenarnya banyak manfaat positif yang bisa dipetik dari kegiatan ini. Manfaat tersebut diantaranya adalah sebagai berikut; (a) melakukan sosialisasi dan memperluas jaringan; (b) ajang promosi; (c) latihan menabung; (d) bertukar informasi

Menurut PSAK 23 revisi 2009 mengungkapkan bahwa penghasilan dalam Kerangka Dasar Penyusunan dan Penyajian Laporan Keuangan sebagai peningkatan manfaat ekonomi selama periode akuntansi dalam bentuk arus masuk atau peningkatan aset atau penurunan liabilitas yang mengakibatkan kenaikan ekuitas, yang tidak berasal dari kontribusi penanam modal dan penghasilan (income) yang meliputi pendapatan (revenue) maupun keuntungan (gain). Menurut (Situmeang, 2018) menyatakan bahwa pendapatan sebagai modal hidup atau modal yang menjalani kehidupan yang dapat memenuhi kebutuhan manusia baik sandang maupun pangan, kebutuhan pendidikan dan kebutuhan lainnya. Selain itu semakin meningkat kebutuhan maka dibutuhkan peningkatan pendapatan masyarakat.

Adapun jenis-jenis pendapatan dari satu kegiatan perusahaan adalah sebagai berikut: (a) pendapatan operasional pada dasarnya pendapatan operasional timbul dari berbagai cara yaitu: pendapatan yang diperoleh dari kegiatan usaha yang dilaksanakan sendiri oleh perusahaan tersebut tanpa penyerahan jasa yang telah selesai diproduksi, pendapatan yang diperoleh dari kegiatan usaha dengan adanya hubungan yang telah disetujui, misalnya penjualan konsinyasi, pendapatan dari kegiatan usaha yang dilaksanakan melalui kerja sama dengan para investor; (b) pendapatan non operasional adalah pendapatan yang diperoleh dari sumber lain diluar kegiatan utama perusahaan yang digolongkan sebagai pendapatan non operasional yang sering juga disebut sebagai pendapatan lain-lain. Pendapatan ini 
diterima perusahaan tidak berkelanjutan namun menunjang pendapatan operasional perusahaan. Timbulnya pendapatan tersebut, dapat disimpulkan bahwa sumber pendapatan meliputi semua hasil yang diperoleh dari bisnis dan investasi.

Biaya adalah semua yang dibebankan dalam suatu kegiatan, antara lain biaya operasional, biaya direct cost atau biaya langsung. Menurut (Umam, Abidin, \& Firmansyah, 2019) menyatakan bahwa biaya digolongkan ke dalam beberapa kategori, hal itu tergantung dengan kebutuhan dan klasifikasinya.

Menurut (Hamel, 2013) menyatakan bahwa piutang usaha perusahaan pada umumnya juga sebagai salah satu aktiva yang besar dan aktiva lancar. Piutang merupakan komponen aktiva lancar yang penting dalam suatu perusahaan, karena aktiva lancar perusahaan yang paling besar setelah kas. Menurut Pernyataan Standar Akuntansi Keuangan (PSAK) No. 43 menyebutkan bahwa, Piutang adalah jenis pembiayaan dalam bentuk pembelian atau pengalihan piutang atau tagihan jangka pendek suatu perusahaan yang berasal dari transaksi usaha". Ikatan Akuntansi Indonesia dalam Pernyataan Standar Akuntansi Keuangan (PSAK) No. 9 mendefinisikan piutang sebagai berikut, "Piutang usaha meliputi piutang yang timbul karena penjualan produk atau penyerahan jasa dalam rangka kegiatan usaha normal perusahaan".

Menurut Pernyataan Standar Akuntansi Keuangan (PSAK) (2009) menyatakan bahwa aset lancar mencakup aset (seperti piutang) yang dijual, dikonsumsi atau direalisasikan sebagai bagian siklus operasi normal meskipun aset tersebut tidak diharapkan untuk direalisasikan dalam jangka waktu 12 bulan setelah periode pelaporan. Berdasarkan beberapa pengertian tersebut dapat dinyatakan bahwa piutang adalah hak penagihan kepada pihak lain atas uang, barang dan/atau jasa yang timbul akibat adanya penjualan barang dan/atau jasa secara kredit.

Adapun penggolongan piutang menurut Standar Akuntansi Keuangan (SAK) yaitu menurut sumber terjadinya, ialah piutang usaha dan piutang lain-lain. Sedangkan pengklasifikasiannya bisa dengan beberapa cara: (a) piutang terdiri dari piutang usaha (trade receivable) dan piutang non usaha (non-trade receivable); (b) piutang terdiri dari piutang yang bersifat lancar atau jangka pendek dan piutang tidak lancar atau piutang jangka panjang.

\section{Metode Penelitian}

Penelitian berlokasi di Distributor Tupperware Pamekasan Madura. penelitian ini menggunakan pendekatan kualitatif, dengan narasumber adalah (a) sumber utama adalah member yang mengadakan arisan (Sugiyono, 2012). (b) sumber pendukung adalah member yang arisan, dan manager Tupperware. Teknik pengumpulan data melalui kegiatan dokumentasi, wawancara, dan observasi. Teknik analisis data yaitu reduksi data, penyajian data (data display), penarikan kesimpulan (verification) (Moleong, 2011).

\section{Hasil dan Pembahasan}

Penjualan menggunakan sistem arisan adalah penjualan produk melalui sejumlah orang yang sudah sepakat untuk membayar iuran pada waktu yang ditentukan. Iuran yang terkumpul saat arisan diserahkan kepada ketua arisan. Selanjutnya, ketua arisan menyerahkan uang kepada yang menang undian arisan. Seseorang yang mendapatkan undian dalam arisan membelikan produk Tupperware. Sistem arisan ini sangat bagus untuk menjual suatu produk 
pada anggota arisan. Anggota arisan ini di dapatkan melalui sosial media dan ada yang tidak menggunakan sosial media.

Berdasarkan hasil pengamatan, wawancara, dan dokumentasi di tempat objek yang bersangkutan dapat disimpulkan bahwa sistem penjualan yang menggunakan sistem arisan ini adalah mengumpulkan sejumlah orang yang sepakat untuk mengadakan arisan dan uang yang terkumpul dari anggota maka akan dibelikan suatu produk Tupperware. Dan arisan ini di undi pada tiap waktu yang telah ditentukan, satu minggu sekali, 15 hari, dan ada yang satu bulan tergantung ketua anggota arisan.

Berdasarkan hasil analisis di obyek penelitian dapat disimpulkan bahwa sistem penjualan produk Tupperware menggunakan sistem arisan sebagai yaitu: (a) mengumpulkan anggota arisan; (b) menentukan iuran yang harus dibayar tiap waktu yang ditentukan; (c) menentukan barang Tupperware yang akan dibelikan ketika mendapatkan arisan.

Penjualan dengan sistem arisan sama dengan menabung tiap minggu atau tiap bulan dan mempermudah konsumen untuk membeli suatu barang. Sistem arisan ini dapat mengatur perekonomian dan melatih menabung sisa uang para ibu rumah tangga. Hal yang sama di kemukakan oleh (Putri \& Suryaningsih, 2018) arisan Tupperware ini supaya bisa mendapatkan Tupperware dengan harga murah dan ringan dalam pembayaran perbulannya, jika dibandingkan dengan kredit tiap bulannya juga mahal belum nanti ada bunganya jadinya lebih memilih ikut arisan ini. Selama mengikuti arisan Tupperware ini merasa belum pernah terjadi konflik ataupun masalah. Dengan adanya penjualan secara sistem arisan ini bisa mendongkrak target poin produk tersebut sehingga bisa menjangkau sampai ke level-level yang lebih tinggi lagi.

Penjualan menggunakan sistem arisan cukup baik dengan sistem arisan yang dana dikumpulkan dari anggota arisan dan di undi pada waktu yang ditentukan. Siapa yang mendapatkanya maka dibelikan produk Tupperware sesuai produk paket arisan senilai jumlah uang arisan dan paket produknya. Seperti yang dikemukakan oleh manajer Tupperware sebagai bahwa Penjualan dengan sistem arisan ini adalah mengumpulkan dana dari anggota arisan dan barang siapa yang mendapatkan arisan maka akan dibelikan produk Tupperware. Penjualan dengan sistem arisan ini akan lebih baik dari member Tupperware yang penjualannya masih belum menggunakan sistem arisan. Mereka yang menggunakan sistem arisan akan lebih banyak menjual produk Tupperware dibandingkan yang tidak menggunakan sistem penjualan dengan sistem arisan.

Penjelasan di atas dapat disimpulkan bahwa penjualan menggunakan sistem arisan adalah penjualan produk melalui arisan yang diundi pada waktu yang tentukan. Penjualan seperti ini sangat baik karena tiap waktu yang ditentukan penjualan ini sudah pasti ada dan volumenya cukup banyak. Penjualan ini sangat kreatif dan sederhana.

\section{Arisan Sebagai Target Poin Ditinjau Dari Aspek Pendapatan}

Pendapat (Yuwita A.P dan Suhesti N., 2012) di tengah persaingan dunia usaha yang semakin ketat seperti sekarang maka setiap perusahaan harus kreatif dan inovatif dalam memproduksi barang yang akan dipasarkan kepada masyarakat. Selain dituntut untuk kreatif dan inovatif perusahaan juga dituntut lebih dalam untuk kegiatan penjualan seperti halnya strategi penjualan untuk mendapatkan sebuah pendapatan yang cukup baik. 
Kehidupan sehari-hari kita sering mendengar istilah pendapatan, dan secara gamblang banyak orang menyebut bahwa pendapatan (itu adalah pemasukan, pemasukan pribadi atau lainya. Menurut Ilmu Ekonomi, pendapatan adalah nilai maksimum yang dapat dikonsumsi oleh seseorang oleh periode dengan mengharapkan keadaan yang sama pada akhir periode semua. Pengertian tersebut menitikberatkan pada total kuantitatif pengeluaran terhadap konsumsi selama satu periode (Novianti, Sutarti, \& Efrianti, 2013).

Pendapatan dalam sistem arisan ini berbeda dengan pendapatan dari sudut pandang akuntansi, yaitu arus masuk bruto dari manfaat ekonomi yang timbul dari aktivitas normal perusahaan selama suatu periode bila arus masuk itu mengakibatkan kenaikan ekuitas, yang tidak berasal dari kontribusi penanam modal. Pendapatan dalam penjualan sistem arisan adalah semua aktivitas penjualan selama arisan itu berlangsung, yang di dalamnya juga terdapat pendapatan finansial dan non finansial yang berupa poin yang bisa di tukar dengan produk, Personal margin, Personal volume bonus, dan Personal recrut bonus.

\section{Arisan Sebagai Target Poin Di Tinjau Dari Aspek Piutang}

Arisan ini sebagai target yang ditinjau dari aspek piutang karena setiap anggota harus bergantian membayar iuran yang sudah menjadi tanggung jawab setiap anggota arisan. Yang disebut piutang dalam arisan adalah iuran dari setiap anggota arisan. Ketua arisan menggunakan sistem cukup baik untuk menjaga anggota arisan rutin seperti tanda tangan diatas materai dan dicatat dalam setiap arisan. Sehingga dengan adanya prasyarat tersebut maka bisa meminimalkan adanya piutang yang tidak lancar atau macet dikarenakan tidak membayar setelah mendapatkan arisan produk tersebut.

Hal tersebut sesuai pendapat (Baihaki \& Malia, 2018) perspektif akuntansi piutang atau investasi. Hal ini karena arisan merupakan sebuah kegiatan transaksional yang mengandung unsur keuangan yang ada unsur manfaat yang diharapkan oleh para pelaku nya. Oleh karena itu, arisan dalam perspektif akuntansi piutang atau investasi yang bisa menjawab bagaimana arisan di Madura dalam perspektif akuntansi piutang dan investasi. Dan banyak member yang mencapai target poin secara cepat karena penjualan yang menggunakan arisan cukup banyak.

Semua member yang menjual produk dengan sistem arisan cukup menjanjikan karena sistem ini tidak merugikan dan memberikan manfaat yang sama pada setiap anggota arisan. Oleh karena itu, Arisan juga tidak hanya mengumpulkan uang, tetapi kadang kala juga produk, bahkan mengumpulkan potensi anggota seperti halnya yang dilakukan oleh member Tupperware untuk mencapai target poin, piutang dalam sistem arisan Tupperware adalah iuran yang harus dibayar oleh setiap anggota arisan Tupperware.

Pada perusahaan dagang atau jasa kegiatan penjualan merupakan salah satu faktor penting penentu keberhasilan perusahaan. Karena dari penjualan inilah dapat diperoleh laba perusahaan. Penjualan dapat dilakukan secara tunai atau kredit. Hampir semua perusahaan melakukan penjualan secara kredit. Hal ini bertujuan untuk mempertahankan pelangganpelanggan yang sudah ada dan untuk menarik pelanggan baru dengan inovasi kebijakan tersebut. ada juga perusahaan yang sistem penjualan yang menggunakan sistem arisan yang mana dalam sistem arisan hampir sama dengan sistem kredit yang mana secara langsung akan menimbulkan piutang terhadap anggota arisan yang melakukan pembelian produk 
Tupperware.

Adanya penjualan secara arisan ini, secara langsung akan menimbulkan akun piutang usaha atau piutang dagang. Piutang merupakan salah satu pos penting dari neraca suatu perusahaan. Semakin tinggi nilai piutang suatu perusahaan juga dapat diartikan semakin tinggi volume penjualan kredit. Suksesnya suatu perusahaan juga dapat dilihat dari pengelolaan piutang yang baik oleh pihak yang berwajib.

Piutang dalam sistem arisan adalah iuran yang menjadi tanggung jawab anggota arisan terhadap anggota yang mendapatkan undian. Berbeda dengan piutang dalam sistem penjualan dalam perusahaan, dari sudut pandang akuntansi adalah salah satu jenis transaksi akuntansi yang mengurus penagihan konsumen yang berhutang pada seseorang atau suatu organisasi untuk barang atau layanan yang telah diberikan pada konsumen tersebut.

\section{Arisan Sebagai Target Poin Di Tinjau Dari Aspek Biaya}

Anggota yang memiliki usaha atau saluran pengeluaran yang bisa menghasilkan manfaat ekonomis lebih besar akan menjadikan arisan sebagai bagian dari sarana untuk mendapatkan pendanaan investasi yang diinginkannya. Karena tolak ukurnya adalah jumlah nominal uang, arisan tersebut bisa dimanfaatkan untuk membiayai pembelian aktiva investasi yang bisa menghasilkan keuntungan turunan dari kegiatan arisan tersebut.

Perspektif investasi tersebut sebenarnya bisa didapatkan dari kedua sisi, baik itu pengurus arisan maupun anggota arisan. Proses interaksi personal dalam bentuk transaksi penghimpunan uang arisan ataupun penyerahan uang arisan oleh anggota telah melahirkan sebuah konsekuensi jasa yang diberikan oleh pengurus dan anggota bersifat sukarela menyerahkan penghimpunan dana pertama arisannya kepada pengurus arisan. Pada saat tersebut telah terjadi transfer aset dari anggota kepada pengurus yang pada saatnya nanti anggota akan menagih sejumlah uang arisan tertentu sebagaimana yang telah disepakati kepada pengurus. Atas uang yang diterimanya oleh pengurus arisan di awal masa arisan bisa dianggap sebagai sebuah investasi Hal tersebut sesuai dengan pendapat (Baihaki \& Malia, 2018).

Setiap perusahaan harus mempertimbangkan atas biaya agar dalam transaksi bisa mencapai tujuan perusahaan tersebut. Dalam mempertimbangkan membutuhkan sebuah manajemen akuntansi agar baik bagi perusahaan dalam operasional. Biaya mempunyai arti uang yang dikeluarkan untuk mengadakan (mendirikan, melakukan) sesuatu, ongkos, belanja, dan pengeluaran.

Biaya dalam sistem arisan Tupperware yang dikeluarkan untuk menjual produk Tupperware pada konsumen adalah biaya operasional yang dikeluarkan oleh member Tupperware seperti transportasi dan konsumi. Ditinjau dari aspek biaya, member yang mengadakan arisan mengeluarkan biaya transportasi dan biaya talangan uang iuran apabila ada anggota arisan yang telat membayar atau tidak membayar. Oleh karenanya, setiap anggota arisan Tupperware bisa menunda alokasi penggunaan uang atau produk yang dimilikinya saat mengikuti arisan. Dengan demikian, anggota arisan mendapatkan uang dengan jumlah yang lebih besar sehingga bisa digunakan sebagai biaya investasi walaupun kemudian anggota arisan Tupperware tersebut harus mengembalikan secara mengangsur. 
Biaya adalah pengorbanan sumber ekonomis yang diukur dalam satuan uang, yang telah terjadi atau mungkin terjadi untuk mencapai tujuan tertentu. Dalam arti sempit biaya merupakan bagian dari harga pokok yang dikorbankan dalam usaha untuk memperoleh penghasilan. biaya diartikan sebagai sumber ekonomi yang harus dikeluarkan demi kelangsungan bisnis yang sedang dijalankan (Sulianto, 2017).

Jadi bisa disimpulkan biaya dalam sistem arisan ini sama dengan definisi dari sudut pandang akuntansi yaitu adalah semua biaya yang harus dikeluarkan oleh member yang mengadakan arisan yang berupa biaya transportasi, konsumsi, dan biaya dana talangan iuran arisan apabila ada anggota yang telat atau tidak membayar uang iuran arisan.

\section{Kesimpulan}

Setelah melakukan analisis dan berdasarkan hasil pengamatan yakni: (a) sistem penjualan dalam Tupperware ada 3 yaitu secara tunai, cicilan, dan arisan. (b) pendapatan dalam penjualan Tupperware berbasis arisan merupakan semua aktivitas penjualan Tupperware dengan sistem arisan itu berlangsung pendapatan yang diterima bisa berupa uang tunai maupun poin yang bisa ditukar dengan produk; (c) piutang dalam sistem arisan adalah cicilan arisan setiap bulannya dari setiap anggota arisan dan menjadi tanggung jawab member yang mengadakan arisan; (d) biaya dalam sistem arisan adalah biaya yang dikeluarkan oleh member Tupperware ketika hadir dalam arisan seperti transportasi, konsumsi, dan dana talangan uang arisan ketika ada anggota arisan yang telat atau tidak membayar. 


\section{Bibliografi}

Baihaki, A., \& Malia, E. (2018). Arisan dalam perspektif akuntansi. Jurnal Akuntansi Multiparadigma, 9(3), 540-561.

Hamel, G. (2013). Evaluasi Sistem Pengendalian Intern Terhadap Piutang Pada PT Nusantara Surya Sakti. Jurnal EMBA: Jurnal Riset Ekonomi, Manajemen, Bisnis Dan Akuntansi, 1(3).

Hendra, R. R. (2018). Peran Promotion Product Dalam Meningkatkan Jumlah Keanggotaan Baru Tupperware Di Banda Aceh (Analisa Strategi Komunikasi Pemasaran Product Tupperware). Jurnal Ilmiah Mahasiswa Fakultas Ilmu Sosial \& Ilmu Politik, 3(2).

Johan, E. T. (2014). Penerapan Target Costing Dalam Upaya Pengurangan Biaya Produksi Untuk Peningkatan Laba Kotor. Jurnal Ilmiah Akuntansi Kesatuan, 2(1), 9-16.

Kartajaya, H. (2007). Boosting Loyalty Marketing Performance: Menggunakan Teknik Penjualan Customer Relationship Management, dan Servis untuk Mendongkrak Laba. Mizan Pustaka.

Lubis, K. S., Syahsudarmi, S., \& Srimulatsih, M. (2018). The Activeness of Women Follow the Arisan Group: A Case Study of Community Groups Vs Professional. IOP Conference Series: Earth and Environmental Science, 175(1), 12089. IOP Publishing.

Meirisa, T., \& Lestari, R. (2020). Strategi Public Relations PT. Ruma Dalam Mempromosikan Program Arisan Mapan. PANTAREI, 4(02).

Moleong, L. J. (2011). Metodologi pendekatan kualitatif. Edisi Revisi, Bandung: Remaja Rosida Karya.

Mulyadi. (2008). Sistem Akuntansi. Jakarta: Salemba Empat.

Novianti, F., Sutarti, S., \& Efrianti, D. (2013). Perlakuan Akuntansi Pengakuan Pendapatan dan Beban Pada Job Pertamina Petrochina East Java. Jurnal Ilmiah Akuntansi Kesatuan, 1(3).

Putri, A. R., \& Suryaningsih, S. A. (2018). Analisis Kegiatan Arisan Dalam Perspektif Islam Di Kelurahan Sememi Surabaya. Jurnal Ekonomika Dan Bisnis Islam, 1(1).

Situmeang, R. R. (2018). Dampak Bisnis Online dan Lapangan Pekerjaan terhadap Peningkatan Pendapatan Masyarakat (Studi Kasus Jasa Bisnis Online Transportasi Grab di Kota Medan). Asian Journal of Innovation and Entrepreneurship, 3(03), 319-335.

Sugiyono. (2012). Metode Penelitian Kuantitatif, Kualitatif dan R \& D.Bandung:Alfabeta. Metode Penelitian Kuantitatif, Kualitatif Dan $R \quad \& \quad$ D.Bandung:Alfabeta. https://doi.org/10.1017/CBO9781107415324.004

Sulianto, P. (2017). Arisan desa untuk biaya pernikahan perspektif 'urf: Studi di Desa Purwokerto Kecamatan Ngimbang Kabupaten Lamongan. Universitas Islam Negeri 
Aminatus Zakhra

Maulana Malik Ibrahim.

Umam, K., Abidin, Z., \& Firmansyah, F. (2019). Analisis Perlakuan Biaya Penyelenggaraan Ibadah Haji Dalam Perspektif Akuntansi. Jurnal Akuntansi, Ekonomi Dan Manajemen Bisnis, 7(2), 119-126.

Yuwita A.P dan Suhesti N. (2012). Bank Sampah untuk Peningkatan Pendapatan Ibu Rumah Tangga. Jurnal Manajemen Bisnis, Vol 2(No 1.). 